Volume 9

Issue 2 Time, Movement, and Space: Genocide

Studies and Indigenous Peoples

$10-2015$

\title{
Moving Beyond The Crossroads: Strengthening the Atrocity Prevention Board
}

James P. Finkel

George Washington University

Follow this and additional works at: https://digitalcommons.usf.edu/gsp

\section{Recommended Citation}

Finkel, James P. (2015) "Moving Beyond The Crossroads: Strengthening the Atrocity Prevention Board," Genocide Studies and Prevention: An International Journal: Vol. 9: Iss. 2: 138-147.

DOI:

http://dx.doi.org/10.5038/1911-9933.9.2.1361

Available at: https://digitalcommons.usf.edu/gsp/vol9/iss2/17

This is brought to you for free and open access by the Open Access Journals at Digital Commons @ University of South Florida. It has been accepted for inclusion in Genocide Studies and Prevention: An International Journal by an authorized editor of Digital Commons @ University of South Florida. For more information, please contact digitalcommons@usf.edu. 


\title{
Moving Beyond The Crossroads: Strengthening The Atrocity Prevention Board
}

\author{
James P. Finkel \\ George Washington University \\ Washington, D.C., USA
}

My recent essay, Atrocity Prevention At the Crossroads: Assessing the President's Atrocity Prevention Board After Two Years, generated considerable interest among former government colleagues, scholars, and non-governmental organizations (NGOs) that follow issues of atrocity prevention and response. ${ }^{1}$ As the waning months of the second Obama administration tick down and the growing field of 2016 Presidential contenders wrestles with how to approach atrocity questions during the campaign, some have asked whether Washington's current approach to atrocity prevention and the functioning of the Board (APB) might be improved. Meanwhile, one of the main challenges for members of the Atrocity Prevention Board will be to become more visible and to demonstrate the utility and effectiveness of their deliberations and tools. The President will need to remind his key foreign policy advisors of the seriousness he attaches to these issues. The APB would benefit from a further public explanation of how the prevention of atrocities is clearly linked to other key US foreign policy goals, including counterterrorism, economic growth and development, reducing poverty, and building rule of law, among other dimensions.

The pages that follow attempt to lay out a number of simple, practical steps that the Board can take to enhance its performance and its visibility vis-à-vis the American public and the international community. Because the Board functions within a broader decision making context, however, more far-reaching change will be necessary for it to meet its full potential. ${ }^{2}$

The President's decision to announce the launch in August 2011 of Presidential Study 10 (PSD 10) aimed at finding more effective ways for the US government to prevent and, failing prevention, respond to atrocities beyond our borders at the US Holocaust Memorial Museum was deliberate. Indeed, the President went so far in that initial speech as to declare the prevention of genocides and mass atrocities a core national security interest and a core moral responsibility of the United States, placing these issues for the first time squarely at the center of an administration's agenda. He returned to the Museum some eight months later in April of 2012 to declare that the study had been completed, that he had accepted all of its recommendations (PSD 10 included over 100 recommendations), and that he was instructing his National Security Council to establish an Atrocity Prevention Board whose job would be to further flesh out the study's findings, put them into practice, and ensure that Washington's efforts to prevent genocides and other forms of mass atrocity would hereafter have real bite. The Board was to consist of representatives from some nine Departments and Agencies at the Assistant Secretary level or above. In short, people who theoretically had a broad enough span of control that they could move personnel and other resources to potential trouble spots whenever and wherever they might be needed.

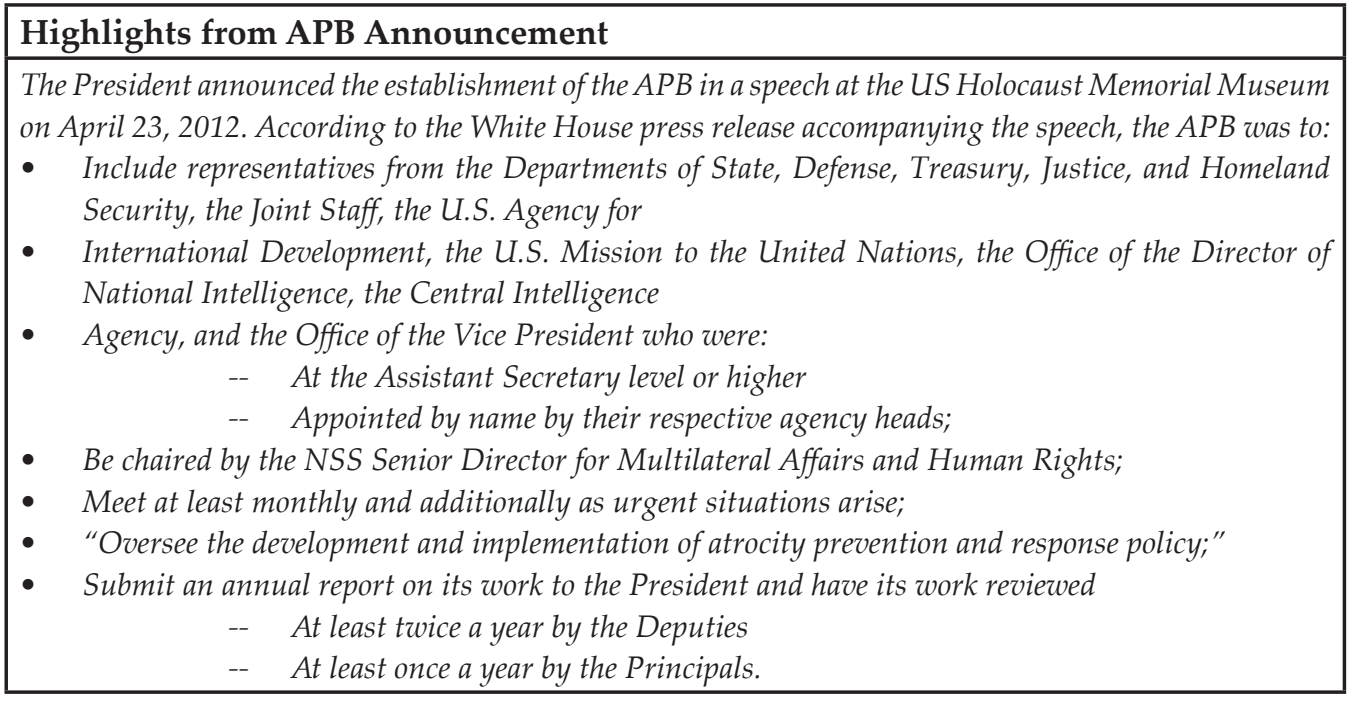


After six months of operations, the APB chair was to draft an Executive Order that would "set forth the structure, functions, priorities, and objectives of the Board, provide further direction for its work, and include further measures for strengthening atrocity prevention and response capabilities as identified in the course of the Board's work." As of this writing, this last prescription has yet to be fulfilled. ${ }^{11}$

The tone and content of the President's speeches, along with the choice of the Museum for their venue, raised expectations among human rights groups both at home and abroad at least initially that a more muscular US atrocity prevention policy was in the offing. This optimism prevailed despite regular admonitions from the Atrocity Prevention Board's first chairperson, then Senior Director for Multilateral and Human Rights Affairs, and current US UN Ambassador Samantha Power, that the P in APB shouldn't be seen as a panacea to the world's problems. ${ }^{3}$ At the same time, however, the announcement prompted nervousness from some quarters within Washington's foreign policy establishment who were already wrestling with wars in Iraq and Afghanistan, dealing with the impact of financial sequestration, and being buffeted by the winds of Arab Spring and quickly deteriorating conditions in Syria. Their concern was that the President was opening the door to additional undertakings at a time when the system was already overloaded.

Among those who had followed atrocity issues for some time, a sense soon emerged that despite having rolled out the APB with considerable fanfare, the President and influential members of the White House staff were stepping away from the initiative. Some prominent participants in the President's newly formed APB bristled privately over the White House's reluctance to further discuss the Board or its work publicly, while the President himself seemed to avoid further references to the Board or its work. An Executive Order that was supposed to have followed the President's announcement of the Board and the acceptance of PSD 10's recommendations was quietly shelved without explanation. While members of the APB and the APB's subordinate group, the sub-APB, occasionally were told by various senior White House officials in the months that followed that the President remained committed to their work and appreciated their efforts, the APB or its counsel rarely seemed to factor into communications or instructions emanating from the White House. The APB fared little better in other key foreign policy Departments and Agencies. For example, one regular participant in the State Department's senior staff meetings noted that while Secretary Clinton had also given an important speech about atrocity prevention at the Holocaust Museum, they were unable to recall an instance in which the issue of taking further steps to strengthen atrocity prevention within the Department as a whole had been broached during those meetings.

Early members of the APB and sub-APB were themselves divided over how much attention to draw to their work in the increasingly toxic domestic political scene that prevailed while the Atrocity Prevention Board was beginning its efforts. Generally speaking, those with prior experience in the advocacy or NGO world were more open to members of the Board and the sub-APB expounding on their work and exchanging views with civil society. Those, on the other hand, who had earned their spurs strictly within the confines of the bureaucracy, were more reticent, fearing that outreach would both further raise expectations about outcomes and result in an enormous drain on their time. Perhaps more importantly, they also feared it would turn what they envisaged as a careful deliberative process into another source of incessant partisan wrangling that would make it more difficult for the Board to achieve its goals.

Board and sub-APB members were also of several minds about how to begin their work program. Although several of the APB's initial members and those who supported the Board in one fashion or another had had a hand in fashioning Presidential Study 10, and had either gone into those discussions as veterans of the Genocide Prevention Task Force ${ }^{4}$ or were at least familiar with the Task Force's recommendations, few anticipated the challenges they would face translating the ideas surfaced during the presidential study into practice within Washington's huge federal bureaucracy. For example, what initially were viewed as relatively simple technical fixes to statutes and laws aimed at closing loopholes that might allow perpetrators of atrocities to enter the US and even obtain residency, led to years of complicated discussion primarily involving State and Justice Department, Homeland Security, and Pentagon lawyers. 
Taking their seats at the APB table with at least two years of government experience-and many with much more - and having experienced the subtle bureaucratic fisticuffs between regional bureaus and their functional counterparts first-hand, most members of the APB initially favored a more cautious approach to the Board's program in hopes that their regional colleagues might more easily be brought along. Thus, for both practical and bureaucratic reasons, the Board opted first to investigate the mechanisms and means it had available to it and to endeavor to fill any gaps with additional tools. The Board and sub-APB devoted considerable time during the Board's initial months to its toolkit. Not everyone agreed that this was the best approach, however. Some Board members and members of the sub-APB argued that it was important for the Board to be seen pushing more aggressively into controversial cases right out of the gate in order for the Board to more firmly establish its bona fides.

Oddly enough, no one with whom I spoke during my research could recall a specific discussion during the PSD 10 deliberations about what exactly prevention was to entail. It may be that the participants considered the meaning implicit. Many had worked on atrocity issues either inside or outside government and felt they had a pretty good idea of what was involved. As one senior State Department official observed some months after the Board had begun operating, the Board hoped it would bring to Washington's foreign policy deliberations a willingness and an ability to think about atrocity prevention and response across the entire spectrum of conflict: pre-conflict, conflict, and post-conflict.

The PSD 10 recommendations were reviewed and endorsed by both the Deputies' and Principals' Committees (with very minor changes) before being forwarded to the President. However, it is not clear how extensive a discussion individual Department and Agency representatives who participated in the PSD 10 discussions had with their senior leaders about the organizational and material implications that standing up a Board chaired by the NSC and tasked with preventing atrocities across the globe would entail. To some extent, this was perhaps less an issue for the first generation of Board members, many of whom like those shaping PSD 10 had either worked on atrocity questions previously, or had strong personal commitment to these issues. But atrocity prevention was a new undertaking even for some members of the initial Board and they, in particular, depended heavily on their subordinates for advice.

A poll of PSD 10 participants, members of the APB, and sub-APB attendees taken at the time the initial Board was standing up probably would have revealed considerable understanding of, and support for, the academic theory involving upstream or pre-conflict prevention. ${ }^{5}$ But manyespecially those with long experience within the bureaucracy-probably would have conceded that prevention, if it was going to be pursued at all, would still most likely be limited to crisis and post-conflict situations. A policy approach geared toward atrocity prevention, especially upstream prevention, would presuppose a significant shift in bureaucratic culture and structure. At the Department of State, for example, Foreign Service Officers are still taught that their primary job is to observe, analyze, and report, but not to interfere. Yet prevention, at any point along the conflict continuum, calls for a much more hands on strategy that includes working with civil society within country, other like-minded states, NGOs, international organization and international financial institutions to articulate a broad range of possible approaches, programs, and policies tailored to fit the specific circumstances in order to avoid, or at least mitigate, the risk of atrocity.

Moreover, as retirements, reassignments, and resignations have prompted rapid turnover among members of the Board and the sub-APB, the consensus about when, how, and under what circumstances prevention should be pursued has become more frayed. This problem has not been limited to a single participating Department or Agency, but has been fairly widespread.

\section{Breaching the Stove Pipes}

Stove piping between the State Department's regional and functional bureaus and within bureaus themselves makes it very difficult for even a Regional Assistant Secretary to obtain a complete understanding of all of Washington's policies, programs, and approaches toward a particular country at any given moment. ${ }^{6}$ Finding ways to breach the stove pipes between and within the regional and functional bureaus, taking a more internally transparent and holistic approach, ought not only to produce more effective policy outputs, but ought to also save taxpayers money over the 
long run. That may not immediately be clear as the State Department, AID, and others wrestle with how to fill the important programmatic gaps that a clearer picture of the sum total of effort toward some countries will inevitably reveal. Some additional personnel and money for further assessment and programming to fill these gaps will undoubtedly be necessary. These investments likely will still be far cheaper than ignoring a situation that risks evolving into a complex humanitarian crisis that may require the use of military force further down the road.

A cursory glance across the many warning and watch lists covering various issues prepared by the
scholarly community and NGO world reveals at least one startling fact: the same twenty or thirty
countries are frequently found at the top/worst position on many of these lists, albeit in different relative
positions. Although the particularities of each of these countries' internal situations will differ, many of
the underlying structural issues contributing to their appearing on one or another of these topic lists
will be at least similar. The length of these lists has traditionally caused considerable angst in some
government quarters with both analysts and policymakers frequently insisting that available time and
resources preclude so broad a focus. The debate has flared in its most recent iteration even among strong
supporters of the APB, with those responsible for actually articulating and implementing prevention
policies generally favoring a narrower, more focused approach while those that believe prevention
requires a broader rethinking of Washington's efforts - those that hope to infuse prevention into the State
Department's DNA - argue that a narrower focus is a prescription for maintaining the status quo.

Atrocity events also tend to take place in out of the way places where we and our key Allies have our smallest diplomatic presence and where that presence increasingly is focused almost exclusively on capitals. Washington desk officers for these countries tend to be more junior and less experienced, as are many of their official counterparts in the field. Changing the incentive structure, for example, by providing more authority, ensuring that desk officers for those countries considered at high risk of atrocities are more experienced and receive the additional training mandated in PSD 10, creating flexible, forward-looking country task forces to break through the stove pipes, would be an important step at the working level toward enhancing prevention. In some situations, it may be that a particular functional issue so predominates Washington's interest, that it makes more sense to give the overall lead of a task force to a functional rather than a regional desk officer. That ought not be a problem under this new arrangement as long as that functional desk officer has considerable experience and as long as they clearly understand that they have been given responsibilities that extend beyond their home unit, and will be evaluated on the basis of that broader undertaking's success or failure.

\section{Attempting To Bridge The Regional/Functional Gap}

At the more senior level, the APB will have to continue to work hard to strengthen ties with the various regional Interagency Policy Committees (IPCs) devoted to particular countries and issues. The impetus for establishing an Atrocity Prevention Board, both on the part of the Genocide Prevention Task Force and the first Obama Administration, arose from a view that human rights issues and atrocity prevention too often had received short shrift from the regional policy bureaus, offices, and committees that typically oversee our bilateral relations.

The original idea was that the NSC's Office of Multilateral and Human Rights Affairs (often referred to within the White House simply as Multilat), whose Senior Director chairs the Atrocity Prevention Board, would serve as a transmission belt, carrying information, ideas, and recommendations back and forth between the APB and the Regional IPC's. Multilat's message, it was thought, would be reinforced at more senior levels by the fact that some APB members also regularly attended meetings of the Deputies' Committee. But no one at the time anticipated the number of atrocity-related issues that the APB would face or the number of related regional IPC meetings that Multilat would be required to attend. Multilat, despite its best efforts, soon found itself hard pressed to keep up with the constant barrage of regional business, and by some accounts sometimes found itself isolated in the face of a regional juggernaut that tended to place greater importance on any number of other issues. 
Meanwhile, despite all of the experience and expertise that individual members of the APB were able to bring to bear on atrocity problems, they normally were not experts on the nitty gritty of the countries being discussed at their monthly APB meetings. Efforts to have NSC regional directors brief the APB during those meetings were rarely satisfactory and left at least some APB attendees feeling that those parts of the meeting were more akin to a courtesy drive-by intended to convince them that they needn't preoccupy themselves with country $x$, rather than a real attempt at collaboration. Attempts to bring Posts directly into the discussion via secure communications generally were more illuminating, but the overall impact of the discussion often turned on the quality of the electronic connection and the Chief of Mission's view as to whether this newly created body would prove to be an ally or a problem during their future interactions with Washington.

Steve Pomper, the principal drafter of the PSD 10 report and Multilat's current Senior Director, to his credit, recognized the challenge of managing relations between the APB and the various regional IPC's early on. He has tried, whenever possible, to organize more joint APB/IPC meetings, with varying success. The sub-APB has likewise tried to reach out more aggressively to its regional counterparts. The truth is that, more often than not, neither the APB nor the regional IPC's can operate at maximum effectiveness without one another's input. Whoever wins the 2016 Presidential election will need to continue to work to improve this part of the system.

Under Secretary of State for Civilian Security, Democracy, and Human Rights Sarah Sewall has devoted considerable attention since coming to office in February 2014 to trying to get the State Department's many voices singing off the same sheet of music on atrocity issues. Sewall has instructed the Bureau of Conflict Stabilization (CSO) to serve as something of a department secretariat for APB matters, gathering the Department's views on subjects being deliberated by the $\mathrm{APB}$ and preparing Department representatives' briefing books for the APB's monthly meetings. CSO has brought on board some additional people to work on atrocity prevention issues, and after a year of work has recently begun to experiment with a new atrocity assessment instrument to be used in conjunction with the Department and AID's broader conflict assessment tool. AID has capped a multi-year effort to consider how atrocity prevention meshes with its traditional mission by publishing a new Field Guide for Atrocity Prevention. The State Department has also asked USIP to develop a new training course for those involved with atrocity issues that will bring some of the latest thinking within academia about atrocity prevention to the table. Other groups outside government are putting the finishing touches on additional training materials as well. For example, the US Holocaust Memorial Museum's Simon-Skjodt Center is in the final stages of preparing to release a new handbook on atrocity prevention. All of these initiatives will reinforce the goals and efforts of the APB. To have the desired impact, however, these new materials and course offerings will have to be broadly disseminated and socialized among Washington's foreign policy corps. The latter, in particular, will require sustained attention and support from senior leadership, which to date, has been sorely lacking.

It may be that as the second Obama Administration winds down and the election season revs up, even more responsibility in these areas will fall to members of the sub-APB, who increasingly will find themselves called upon to use their personal ties throughout the bureaucracy, rather than rank and position, to lead from the middle in order to get things done. The origin of several of the APB's initiatives can already be traced to people associated at one time or another with the subAPB, initially made up of some of the people who have worked longest on these issues, who have been closer to day-to-day developments in many of the at risk countries than more senior members of the APB, and who often have had a better understanding of the various financial accounts and what they can and can not be used for. The sub-APB more recently has suffered from some of the same problems of turnover as its parent body. It will need to continue to work hard to bring its newcomers up to speed and with their support keep the initiatives coming and the momentum going. One way the sub-APB might be able to help maintain that momentum would be to work with the APB's chairperson to firmly embed a series of benchmarks into the APB process.

\section{Step By Step}

The GPTF devoted considerable space to early warning and argued strongly that the Intelligence Community (IC) ought to produce for the White House and what has emerged as the APB, a full- 
blown annual National Intelligence Estimate (NIE) outlining the global risk of atrocities. ${ }^{7}$ Some members of the GPTF appear to have felt strongly that an NIE- which would reflect the formal views of the entire Intelligence Community-would not only carry more weight with senior policymakers, but would ease the flow of collection resources to atrocity questions by illuminating the risks to senior Intelligence leaders through the NIE process. Following the publication of the Intelligence Community's first-ever estimate on the Global Risk of Mass Atrocities-a document that drew positive reviews from across government-a senior State Department's functional bureau official echoed the GPTF's sentiments that having an NIE made it easier for them to urge their regional counterparts to take seriously the risk of atrocities in their countries of responsibility. The estimate seems unlikely to have had the type of strong impact on collectors that GPTF members hoped, however, as most long-term collection priorities generally are decided through a separate, formal process. NIEs normally are a substantial undertaking and very few are done on an annual basis, although an NIE on the global risk of atrocities every four years would not seem unreasonable. While some NIE's have been completed fairly quickly under special circumstances, the average time - in order to allow for all of the required formal meetings and steps - is about nine months. The NIE's utility in helping agencies to prioritize their efforts in real time is thus limited.

Clearly some sort of annual assessment from the IC needs to be central to the APB process. In fact, the IC has a number of assessment art forms available that are similar to an NIE. They normally are not coordinated as broadly, nor at as senior a level, and they lack the panache of an NIE. However, they undergo rigorous review and are simpler to produce annually. Indeed, as PSD 10 participants were completing the draft of their report in November 2011, members of the IC were already at work on a broad assessment of the global risk of atrocities that was being prepared in anticipation of an initial meeting of the APB. ${ }^{8}$ That all-source assessment was drawn from a combination of quantitative modeling, structured expert and post surveys, an intense review of published NGO reports, and a close read of other government reporting and analysis. While some might view the final product as failing to carry the weight of an NIE, in substantive terms there would seem no particular reason why this type of assessment could not substitute for a formal NIE during most years.

This ought especially to be the case if the IC continues its initial practice of providing the Board detailed monthly updates on each country that appeared in its annual assessment along with a context assessment of a country singled out each month by the Board for deeper study. The format of the IC's monthly briefing packages was flexible enough that it allowed the Intelligence Community to bring to the Board's attention situations that might not have factored into its annual assessment, but were subsequently showing worrisome signs.

One question the Board will need to decide, and the sub-APB could usefully tee up, is when during the year the Board would like to receive the IC's annual atrocity risk assessment, which presumably ought to signal the start of the Board's work program for the next twelve months. Three options immediately come to mind: the beginning of the fiscal year, the beginning of the calendar year, and late spring. Using the beginning of the fiscal year would put the APB on the same calendar as many other government undertakings. Early January would have the advantage of coming right after the holidays when senior policymakers traditionally find some down time to ponder the last six months and consider what might lie ahead. Early spring, on the other hand, is when some of the data sets the IC draws on are refreshed. It is also the time of year when Departments and Agencies are beginning to update their budgets and plans for the upcoming fiscal year, and refining their out-year plans. Many policymakers also try to set time aside to assess where issues stand and where they hope to direct things through the end of the fiscal year. Working backwards from whatever date is chosen, the IC would begin its part of the process by sending a structured atrocity prevention questionnaire to posts world-wide and the appropriate government analysts in order to begin generating one of several important inputs to its analysis.

Organize Annual Off-site

Under the best of circumstances, completion of the annual IC atrocity risk assessment would be followed soon after by an annual off-site bringing together, at a minimum, members of the APB and sub-APB, Regional Assistant Secretaries, and senior NSC regional directors. ${ }^{9}$ The centerpiece of 
that meeting would be a presentation by the IC of that assessment followed by a broad discussion amongst the assembled policymakers of the report's implications. The meeting would also provide attendees an opportunity to compare the IC's atrocity risk list with other governmental and nongovernmental lists focused on such issues as political instability/fragility, terrorism, corruption, human rights, proliferation, complex humanitarian emergencies, drugs, human trafficking, etc. The goal of the meeting would be not only to try to help narrow the gap between the functionalists and regionalists on a range of atrocity prevention related issues, but also to begin breaking down the stove pipes at a senior level and focusing on common structural drivers and potential policy responses.

The meeting would also offer an opportunity on an annual basis to revisit the question more holistically at a fairly senior level of what prevention is supposed to mean and what recent experience is telling us about what works and what doesn't. ${ }^{10}$ It would likewise allow for a discussion of what type of atrocity prevention (or combination of prevention) - pre-conflict, conflict, or post-conflict might be most appropriate for each country that the IC has highlighted. Finally, the meeting might also allow Departments and Agencies to bring to the table additional country information that had not previously been shared outside the stovepipes, or that might otherwise be overlooked. This includes materials like AID's excellent Country Development Cooperation Strategies that tend to include a wide range of information relevant to atrocity prevention.

\section{Alert Country Missions}

$\mathrm{CSO}$, as the State Department's recently designated secretariat for atrocity prevention matters, would seem the logical candidate to plan and organize the off-site. CSO would also have responsibility for keeping the meeting's minutes, from which a special reporting message would be prepared for those diplomatic missions in the top twenty or more countries that appear on the IC's atrocity risk list. That message would formally alert the Chief of Mission that his country was on the IC's list, explain the reasons behind its inclusion, and summarize the discussion about their country that had taken place. It would also instruct the Chief of Mission to designate a senior coordinator for atrocity prevention, who depending on the size and make up of the Mission might be the Deputy Chief of Mission, the Political Counselor, or the Senior AID Administrator. Copies of those messages would also be transmitted simultaneously through military and intelligence channels to appropriate Regional Combatant Commanders, Senior Defense Attaches, Chiefs of Station, and Treasury representatives and would put them on record that they are to provide appropriate support to the Mission's prevention efforts.

\section{Initiate Horizontal and Vertical Dialogue}

The designation of an atrocity prevention coordinator at each relevant Mission should set in motion two related dialogues, one within the Mission country team that would consider the feedback from the annual Washington off-site, organize a preliminary Mission assessment by the country team, review the Mission's existing programs that contribute to atrocity prevention, and begin the process of identifying key gaps. The second dialogue would be between the Mission country team, the $\mathrm{APB}$, and the appropriate regional IPC.

\section{Carry Out Conflict/Atrocity Assessment}

As part of that latter discussion, the APB/IPC/Mission country team would jointly agree to organize and schedule a multi-agency, multidisciplinary conflict and atrocity assessment with CSO and AID as co-leads. Although AID and CSO have done pioneering work aimed at adopting conflict/ atrocity assessments within the US government, their methods have still to gain broad acceptance. Good conflict/atrocity assessments cover a broad range of topics and are labor intensive. All too often Chiefs of Mission who are less familiar with the practice and wary of having Washington play in their sandbox-especially if the outcome could be a report that conveys bad news, or at least a storyline that deviates from the picture that the Mission heretofore has been conveying-have been reluctant to host these groups. Arguments frequently have ranged from hosting up to a dozen team members for a few weeks would overwhelm the Mission's resources to concerns that their presence would quickly become known and would raise the hackles of the host government. 
Past members of the APB have marveled at some of the obstacles that have been raised by Missions and home bureaus following proposals from the APB that they host a conflict/atrocity study team. From the APB's perspective, it was offering an opportunity to bring additional resources to bear on what were often small, out of the way Missions that under sequestration likely found themselves even more resource strained than usual. The APB saw the studies as an initial step to try to get ahead of problems and to gain better understanding of conflict and potential atrocity at the local level. A given conflict/atrocity assessment rarely, if ever, provides the last word. Instead it renders a snapshot of where things stand at a given moment. The scholarly literature suggests that they can be most effective as part of an ongoing process. In those instances where Chiefs of Mission have been open to hosting these study teams, even on a one-time basis, the results according to most accounts, have been very positive. For Washington, when Missions have been on board, the challenge has been to find the appropriate personnel and funds to respond to the demand. One advantage of widening participation of the annual off-site as suggested above is that bringing the regional IPC's into the discussion at that stage ought to help reassure at least some skeptical Chiefs of Mission, especially if the meeting achieves buy in and holds the promise of easing the future flow of resources to Missions. It should also serve to free up positions and money necessary to meet the anticipated demand for additional studies.

\section{Seek Out Like-Minded Allies}

Similar dialogues will also need to be initiated or strengthened where they already exist with likeminded partners in Mission states, in Washington, and in other capitals. Seeking the views of civil society, the NGO community, other bilateral missions, key international organizations like the $\mathrm{UN}$, and international financial institutions, especially locally, will be key to better understanding individual situations within countries and orchestrating more effective initiatives while avoiding harm. Regular sharing of information and coordination of different programs locally have proved invaluable in a variety of situations. But US policy would also benefit from a more regular, structured discussion about the risk of atrocities with a variety of like-minded partners in Washington, with UN offices in New York, including the office of the Special Advisors on Genocide and R2P, DPKO, and the Peace Building Commission, among others, and appropriate offices within the EU, OSCE, OAS, ASEAN and the AU, including the latter's subordinate regional organizations. Each of these elements has had their own experiences wrestling with prevention and both they and Washington could benefit from a regular exchange of views encompassing both theory and practice.

One means of helping to facilitate those interactions might be to reinstitute and expand the Annual Genocide Prevention Conference that Washington hosted for five consecutive years until funds dried up. Organized at the working level, these meetings brought together representatives from some fourteen governments, civil society, and leading members of the scholarly community for frank, unclassified, off-the-record discussions of methodologies for determining risk, evolving norms, links between prevention and development and a variety of other related topics. While most of the sessions were open to all participants, the meetings were also arranged to allow time for some restricted multilateral discussions of more sensitive issues.

On a more day-to-day basis, it will be up to the APB's chairperson, working in conjunction primarily with the Department of State, to decide at the end of each monthly APB meeting which partners might be usefully engaged, whether Washington or a specific bilateral Mission is best suited to do it, ensure that it is included in the list of tasks assigned after each meeting, and then check systematically to ensure that the contacts actually take place.

\section{Country Task Forces}

As the country conflict/atrocity assessments are completed, the APB should task the Department of State to establish a series of intra-Departmental, inter-Agency, country-specific, multi-disciplinary atrocity prevention task forces to consider the assessments' findings, take into account information that has been gleaned from other partners and any additional studies that might be commissioned and, in conjunction with the Mission Country Team, make specific policy recommendations to the APB and the appropriate regional IPC. (To maximize efficiency, the Task Forces would also share the information they have gathered and their recommendations with the Regional Commands' 
contingency planning cells and other appropriate government planning bodies.) Assuming those recommendations are approved by the $\mathrm{APB}$ and regional IPC, and any higher approvals that might be necessary are obtained, it would then be left to the appropriate parts of the Washington foreign policy community and, especially, the Mission Country Team to see them implemented, with the task forces continuing to monitor progress on a regular basis and to undertake additional formal assessments at agreed intervals.

\section{Looking Ahead}

The path to preventing atrocities in the future is likely to lie less in big theoretical breakthroughs and more in the direction of better coordination and integration of policy approaches, both within our own government and with key like-minded partners. The remaining months of the second Obama Administration will, it is hoped, see the APB and its regional counterparts double-down on their efforts to narrow the chasm that continues to divide functionalists from regionalists, identify additional resources that can be made available as the economy improves, and identify a variety of common drivers and ways to possibly mitigate them.

By the end of the second Clinton Administration those who were associated with the Interagency Atrocity Prevention Working Group that Ambassador Dave Scheffer - Washington's first Ambassador-at Large For War Crimes - had organized felt that their group an

$\mathrm{d}$ the approaches they were developing were on the verge of having a strong impact on policy. Regrettably, the Scheffer group and the infrastructure it was beginning to create were swept away by a combination of political vitriol and different philosophies about how government Departments and Agencies should be organized. It was eight long years before the first Obama Administration would seriously revisit the approach that Scheffer had pioneered and establish a much more sophisticated model with the APB, valuable time wasted in the minds of those who longed to enter the fray. Hopefully, whatever Administration eventually succeeds Obama II will seek to learn from and build on the Atrocity Prevention Board experience rather than simply cast it aside.

\section{Endnotes}

1 James P. Finkel, Atrocity Prevention At The Crossroads: Assessing The President's Atrocity Prevention Board After Two Years (Washington, DC: United States Holocaust Memorial Museum Center for the Prevention of Genocide, 2014). Available from: http://www.ushmm.org/m/pdfs/20140904-finkel-atrocity-preventionreport.pdf (accessed 24 June 2015).

2 The author wishes to acknowledge the United States Holocaust Museum's Simon-Skjodt Center's support during the preparation of the original article cited above. The Center also hosted a roundtable in November 2014 focused on that article which surfaced some additional ideas that the author has further developed in the current draft. The conclusions reached in this essay - along with any possible mistakes - however, are strictly the author's own. The views expressed in this article do not necessarily represent the views of the author's former Federal employer, other Federal Departments or Agencies, the Simon-Skjodt Center, or the US Holocaust Memorial Museum.

3 The White House reiterated Power's cautionary note in an updated "Fact Sheet" in May 2013, one of the few times since the roll out of the Atrocity Prevention Board that the Board has been mentioned officially. See https://www.whitehouse.gov/blog/2013/05/01/update-atrocity-prevention-strategy-implementation (accessed 3 August 2015).

4 Madeleine K. Albright and William S. Cohen, Preventing Genocide: A Blueprint for U.S. Policymakers (Washington, DC: The United States Holocaust Memorial Museum, The American Academy of Diplomacy, and The Endowment of The United States Institute of Peace, 2008). Available from: http://www.ushmm. $\mathrm{org} / \mathrm{m} / \mathrm{pdfs} / 20081124$-genocide-prevention-report.pdf (accessed 24 June 2015). In US policy circles, the text is often referred to by the acronym GPTF.

5 For useful discussions of prevention see Oliver Ramsbotham, Tom Woodhouse, and Hugh Miall, Contemporary Conflict Resolution, Third Edition (Cambridge: Polity Press, 2012); and Paul B. Stares and Micah Zenko, Enhancing U.S. Preventive Action: Council on Foreign Relations, Special Report No. 48 (New York: Council on Foreign Relations Press, 2009).

6 Stove piping in this context refers to the common practice of developing approaches and policies within a very circumscribed circle or chain of command rather than seeking greater inclusion. Stove piping sometimes evolves in large bureaucracies as a practical approach to getting things done. Stove piping can also be used, however, to limit discussion and the influence of rival offices, Agencies, and Departments. 
7 Albright and Cohen, Preventing Genocide, 17.

8 Finkel, Atrocity Prevention At The Crossroads, 14.

9 The States Department's 2015 Quadrennial Diplomacy and Development Review refers to a separate Presidential Policy Directive on Global Development. This Directive presumably governs at least some of the activities of a small IPC on global political fragility or instability that has functioned separately from the APB. Given the likely overlap between countries that both groups follow, it would make enormous sense for members of the Fragility IPC to participate in the annual off-site as well. See http://www.state. gov/s/dmr/qddr/2015/index (accessed 25 June 2015), 19.

10 Finkel, Atrocity Prevention At The Crossroads, 20.

11 White House, "Fact Sheet: A Comprehensive Strategy and New Tools to Prevent and Respond to Atrocities." Available from: http://www.whitehouse.gov/the-press-office/2012/04/23/fact-sheet-comprehensivestrategy-and-new-tools-prevent-and-respond-atro (accessed 25 August 2015). 